\title{
Two New Coumarins from Herpetospermum caudigerum
}

\author{
Mei Zhang,* Yun Deng, Hong-Bin Zhang, Xiao-Lin Su, Hu-Lan Chen, Tian Yu, and Ping Guo \\ College of Pharmacy, Chengdu University of Traditional Chinese Medicine; Chengdu, Sichuan 610075, P. R. China. \\ Received July 31, 2007; accepted November 9, 2007; published online November 12, 2007
}

The ethyl acetate extract from the seeds of Herpetospermum caudigerum was found to show protective effects on carbon tetrachloride $\left(\mathrm{CCl}_{4}\right)$ and thioacetamide (TAA)-induced acute hepatic injuries in mice. From the ethyl acetate extract, two new coumarins, herpetolide A (1) and herpetolide B (2), along with four known compounds, herpetone (3), dehydrodiconiferyl alcohol (4), 2,4-dihydroxypyrimidine (5) and stigmasterol (6) were isolated. The structures of the new coumarins were elucidated on the basis of chemical and physicochemical evidences. Herpetone exhibited protective effects on $\mathrm{CCl}_{4}$-induced hepatocyte injury.

Key words Herpetospermum caudigerum; herpetolide A; herpetolide B; coumarin; herpetone

Herpetospermum caudigerum WALL (H. pedunculosum (SER.) BAILl.) (Cucurbitaceae) is distributed in southwest China, Nepal, and northeast India. The dried ripe seeds of $H$. caudigerum have been used for the treatment of liver diseases as a Tibetan medicinal herb in China. ${ }^{1)}$ The ethyl acetate extract from the seeds of $H$. caudigerum was found to show protective effects on carbon tetrachloride $\left(\mathrm{CCl}_{4}\right)$ and thioacetamide (TAA)-induced acute hepatic injuries in mice. ${ }^{2)}$ From the ethyl acetate extract, a new sesqui-norlignan named herpetone was obtained during our study. ${ }^{3)}$ The continued study led to the isolation of two new coumarins named herpetolide A (1) and herpetolide B (2), along with herpetone (3), dehydrodiconiferyl alcohol (4), ${ }^{4)}$ 2,4-dihydroxypyrimidine $(5)^{5)}$ and stigmasterol $\left.(\mathbf{6})^{6}\right)$ from the ethyl acetate extract. The structures of the new coumarins were determined on the basis of chemical and physicochemical evidences.

Compounds 1 was isolated as a white amorphous powder. Its molecular formula $\mathrm{C}_{16} \mathrm{H}_{14} \mathrm{O}_{6}$ was established from the quasi-molecular ion peak at $\mathrm{m} / z 325.0682[\mathrm{M}+\mathrm{Na}]^{+}$in the HR-ESI-MS. The IR spectrum suggested the presence of hydroxyls $\left(3384 \mathrm{~cm}^{-1}\right)$, a carbonyl group $\left(1688 \mathrm{~cm}^{-1}\right)$, and benzene rings $\left(1612,1522,1453 \mathrm{~cm}^{-1}\right)$. The presence of a 1,2,4,5-tetrasubstituted benzene ring and a 1,2,3,5-tetrasubstituted benzene ring were indicated from the ${ }^{1} \mathrm{H}-\mathrm{NMR}$ spectrum $(\delta 8.02,1 \mathrm{H}, \mathrm{s}$ and $\delta 7.58,1 \mathrm{H}, \mathrm{s} ; \delta 7.05,1 \mathrm{H}, \mathrm{d}$, $J=2.6 \mathrm{~Hz}$ and $\delta 6.93,1 \mathrm{H}, \mathrm{d}, J=2.6 \mathrm{~Hz}$ ), which was supported by the corresponding 12 downfield signals in the ${ }^{13} \mathrm{C}$ NMR. The ${ }^{1} \mathrm{H}$ - and ${ }^{13} \mathrm{C}$-NMR spectrum of $\mathbf{1}$ also suggested the presence of a hydroxymethyl group $\left(\delta_{\mathrm{H}} 5.73,1 \mathrm{H}, \mathrm{t}\right.$, $J=5.0 \mathrm{~Hz}, \delta_{\mathrm{H}} 4.89,2 \mathrm{H}, \mathrm{d}, J=5.0 \mathrm{~Hz}$ and $\left.\delta_{\mathrm{C}} 63.8\right)$, two methoxyl groups $\left(\delta_{\mathrm{H}} 3.96\right.$ and 3.83 , each $3 \mathrm{H}, \mathrm{s} ; \delta_{\mathrm{C}} 56.2$ and 56.0) and a conjugated carbonyl group $\left(\delta_{\mathrm{C}} 160.5\right)$. A detailed comparison of ${ }^{1} \mathrm{H}$ - and ${ }^{13} \mathrm{C}-\mathrm{NMR}$ data between 1 and reference data of similar compound reported by Tanahashi T. et $a l .^{7)}$ implied that 1 possessed the similar coumarin skeleton. The HMBC correlations between $\mathrm{CH}_{2} \mathrm{OH}(\delta 4.89)$ and $\mathrm{C}-4 \mathrm{a}$ $(\delta$ 111.1), C-5 ( $\delta 140.1), \mathrm{C}-6(\delta$ 115.0), along with the NOESY correlation between $\mathrm{CH}_{2} \mathrm{OH}\left(\delta\right.$ 4.89) and $\mathrm{H}^{-1}{ }^{\prime}(\delta$ $8.02)$, H-6 ( $\delta 6.93)$, indicated that the hydroxymethyl was located at C-5. Moreover, it was deduced that the hydroxy and two methoxyl groups were located at C-7, C-2' and C- $3^{\prime}$ respectively by the HMBC and NOESY experiments (Fig. 2). Consequently, compound $\mathbf{1}$ was elucidated as the structure showed in Fig. 1, and was trivially named as herpetolide A.
Its ${ }^{1} \mathrm{H}$ - and ${ }^{13} \mathrm{C}$-NMR spectra (Table 1 ) were completely assigned by detailed DEPT, HMQC, HMBC and NOSEY experiments.

Compound 2 was obtained as a white amorphous powder. Its molecular formula $\mathrm{C}_{16} \mathrm{H}_{12} \mathrm{O}_{6}$ was established from the quasi-molecular ion peak at $\mathrm{m} / z 323.0523[\mathrm{M}+\mathrm{Na}]^{+}$in the HR-ESI-MS. The IR spectrum suggested the presence of hydroxyls $\left(3356 \mathrm{~cm}^{-1}\right)$, carbonyl groups $\left(1725,1674 \mathrm{~cm}^{-1}\right)$, and benzene rings $\left(1622,1523,1455 \mathrm{~cm}^{-1}\right)$. The ${ }^{1} \mathrm{H}-$ and ${ }^{13} \mathrm{C}$-NMR spectra of $\mathbf{2}$ were similar to those of $\mathbf{1}$, except for the difference of CHO signals in $2\left(\delta_{\mathrm{H}} 10.51,1 \mathrm{H}, \mathrm{s}\right.$ and $\delta_{\mathrm{C}}$ $192.6)$ and $\mathrm{CH}_{2} \mathrm{OH}$ signals in $1\left(\delta_{\mathrm{H}} 5.73,1 \mathrm{H}, \mathrm{t}, J=5.0 \mathrm{~Hz}, \delta_{\mathrm{H}}\right.$ $4.89,2 \mathrm{H}, \mathrm{d}, J=5.0 \mathrm{~Hz}$ and $\left.\delta_{\mathrm{C}} 63.8\right)$. The HMBC of 2 also revealed that the $\mathrm{CHO}$ was located at $\mathrm{C}-5$. Thus, compound 2 was determined as the structure showed in Fig. 1, and was trivially named as herpetolide $\mathrm{B}$. Its ${ }^{1} \mathrm{H}$ - and ${ }^{13} \mathrm{C}-\mathrm{NMR}$ spectra (Table 1) were assigned by detailed 2D-NMR experiments.

In order to seek the bioactive constituents for the treatment of liver diseases, effects of herpetone, a lignan compound of

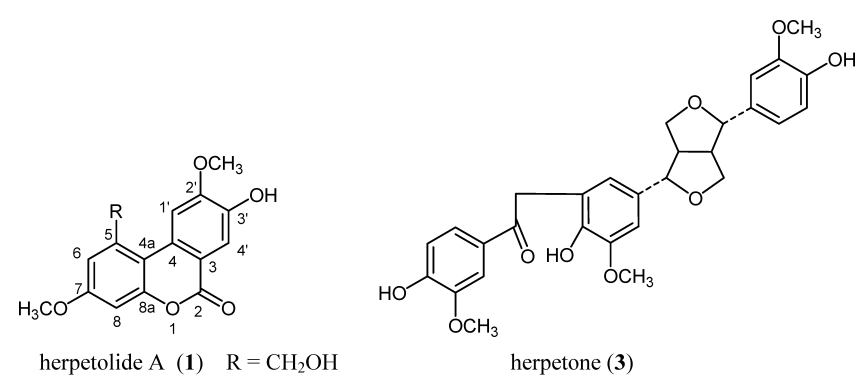

herpetolide $\mathrm{B}(2) \quad \mathrm{R}=\mathrm{CHO}$

Fig. 1. Structures of Herpetolide A, B and Herpetone from the Seeds of H. caudigerum
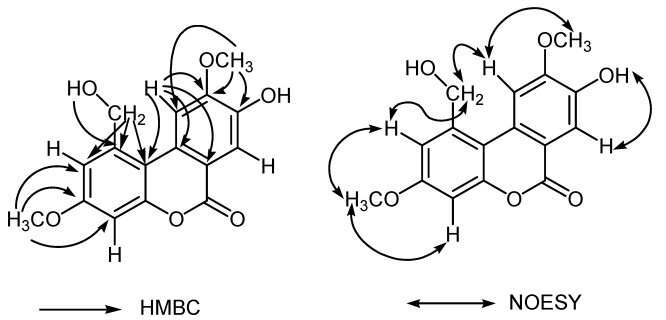

Fig. 2. Important HMBC and NOESY Correlations of Herpetolide A HMBC: $\rightarrow$; NOESY: $\leftrightarrow$ 
Table 1. ${ }^{1} \mathrm{H}-$ and ${ }^{13} \mathrm{C}-\mathrm{NMR}$ Data of 1 and $2\left(600 / 150 \mathrm{MHz}\right.$, DMSO- $d_{6}, \delta$ in ppm, $J \mathrm{~Hz}$ )

\begin{tabular}{|c|c|c|c|c|}
\hline \multirow{2}{*}{ Position } & \multicolumn{2}{|l|}{1} & \multicolumn{2}{|l|}{2} \\
\hline & $\delta_{\mathrm{H}}$ & $\delta_{\mathrm{C}}$ & $\delta_{\mathrm{H}}$ & $\delta_{\mathrm{C}}$ \\
\hline 2 & & 160.5 & & 160.0 \\
\hline 3 & & 113.6 & & 113.8 \\
\hline 4 & & 128.9 & & 126.5 \\
\hline $4 a$ & & 111.1 & & 112.4 \\
\hline 5 & & 140.1 & & 135.9 \\
\hline 6 & $7.05,1 \mathrm{H}, \mathrm{d}(2.6)$ & 115.0 & $7.31,1 \mathrm{H}, \mathrm{d}(2.6)^{a)}$ & 114.7 \\
\hline 7 & & 159.3 & & 159.6 \\
\hline 8 & $6.93,1 \mathrm{H}, \mathrm{d}(2.6)$ & 101.4 & $7.29,1 \mathrm{H}, \mathrm{d}(2.6)^{a)}$ & 106.7 \\
\hline $8 \mathrm{a}$ & & 152.8 & & 152.9 \\
\hline $1^{\prime}$ & $8.02,1 \mathrm{H}, \mathrm{s}$ & 109.7 & $7.30,1 \mathrm{H}, \mathrm{s}$ & 110.2 \\
\hline $2^{\prime}$ & & 154.3 & & 154.2 \\
\hline $3^{\prime}$ & & 147.1 & & 148.4 \\
\hline $4^{\prime}$ & $7.58,1 \mathrm{H}, \mathrm{s}$ & 114.6 & $7.61,1 \mathrm{H}, \mathrm{s}$ & 114.2 \\
\hline$-\mathrm{CH}_{2} \mathrm{OH}$ & $5.73,1 \mathrm{H}, \mathrm{t}(5.0)$ & 63.8 & & \\
\hline & $4.89,2 \mathrm{H}, \mathrm{d}(5.0)$ & & & \\
\hline 7- $\mathrm{OCH}_{3}$ & $3.83,3 \mathrm{H}, \mathrm{s}$ & 56.0 & $3.91,3 \mathrm{H}, \mathrm{s}$ & 56.3 \\
\hline $2^{\prime}-\mathrm{OCH}_{3}$ & $3.96,3 \mathrm{H}, \mathrm{s}$ & 56.2 & $3.95,3 \mathrm{H}, \mathrm{s}$ & 56.6 \\
\hline$-\mathrm{OH}$ & $9.98,1 \mathrm{H}, \mathrm{brs}$ & & $10.26,1 \mathrm{H}$, br s & \\
\hline$-\mathrm{CHO}$ & & & $10.51,1 \mathrm{H}, \mathrm{s}$ & 192.6 \\
\hline
\end{tabular}

a) Chemical shift may be exchanged.

Table 2. Effects of Herpetone on the Survival Rate of Rat Hepatocytes Treated with $\mathrm{CCl}_{4}$

\begin{tabular}{lccc}
\hline \hline Group & Dose $(\mathrm{mg} / \mathrm{ml})$ & OD $($ mean \pm S.D. $)$ & Survival rate $(\%)$ \\
\hline Medium & & $0.545 \pm 0.06^{\mathbf{\Lambda}}$ & 100 \\
$\mathrm{CCl}_{4}$-treated & & $0.127 \pm 0.02$ & 23.3 \\
Herpetone & 0.5 & $0.257 \pm 0.01$ & 47.1 \\
& 0.25 & $0.168 \pm 0.04$ & 30.8 \\
& 0.125 & $0.148 \pm 0.01$ & 27.1 \\
& 0.0625 & $0.142 \pm 0.01$ & 26.0
\end{tabular}

Compared with $\mathrm{CCl}_{4}$-treated, $\mathbf{\Delta} \mathbf{4} p<0.01$.

relatively high content isolated from the EtOAc extract of $H$. caudigerum, on the survival rate of $\mathrm{CCl}_{4}$-injured primary cultured rat hepatocytes were investigated (Table 2). The result showed that herpetone significantly improved the cell viability, indicating a protective effect on hepatocytes in vitro. In addition, Yuan et al. reported that herpetin, another lignan compound from this plant, showed significant inhibitory effects on HBV-DNA and the replication and expression of HBsAg and $\mathrm{HBeAg}$. ${ }^{8)}$ These findings suggest that lignan constituents of this plant are worthy of further investigation.

\section{Experimental}

General Melting points were measured on an XRC-1 melting point apparatus and are uncorrected. UV and IR spectra were recorded on a UV8500 spectrometer and a Nicolet 2000XV FT-IR spectrometer (KBr disk), respectively. Mass spectra were obtained on a VG-7070E mass spectrometer (EI-MS) and a Bruker Daltonics Bio TOF-Q mass spectrometer (HR-ESIMS). NMR spectra were carried out on a Bruker Avance 600 spectrometer with TMS as the internal standard. Column chromatography was carried out on silica gel (200-300 mesh), Qingdao Haiyang Chemical Group Co., China). Semi-preparative HPLC was carried out using a Shimadzu 10A VP HPLC system (YWG-C ${ }_{18}$ column, $250 \times 10 \mathrm{~mm}, 10 \mu \mathrm{m}$ ).

Plant Material The seeds of $H$. caudigerum were purchased from Tibetan Shannan Herbal Company and identified by Prof. Minru Jia, College of Pharmacy, Chengdu University of Traditional Chinese Medicine (TCM). Voucher specimens (No. 2001-018a) have been deposited at the phytochemistry laboratory of Chengdu University of TCM.
Extraction and Isolation The dried and powdered seeds of $H$. caudigerum $(5.3 \mathrm{~kg})$ were refluxed with $95 \%$ ethanol $(401 \times 4$ times, each $2 \mathrm{~h}$ ). After removal of ethanol under reduced pressure, $370 \mathrm{~g}$ of residue was obtained. Mixed well with silica gel $(1 \mathrm{~kg})$, this residue was extracted in turns with petroleum ether, ethyl acetate, and $95 \%$ ethanol. After removal of solvents under reduced pressure, $90 \mathrm{~g}$ of petroleum ether extract, $30 \mathrm{~g}$ of ethyl acetate extract, and $45 \mathrm{~g}$ of ethanol extract were obtained.

The ethyl acetate extract $(30 \mathrm{~g})$ was subjected to silica gel column chromatography $(\phi 6 \times \mathrm{L} 50 \mathrm{~cm})$ and eluted with petroleum ether/ethyl acetate $(6: 1,3: 1,1: 1,1: 2)$ to give fractions $\mathrm{A}-\mathrm{D}(\mathrm{A}, 1.8 \mathrm{~g} ; \mathrm{B}, 1.2 \mathrm{~g} ; \mathrm{C}, 0.6 \mathrm{~g} ; \mathrm{D}$, $2.0 \mathrm{~g})$. Compound $1(12 \mathrm{mg})$ was obtained by crystallization of fraction A from petroleum ether/ethyl acetate, while the remnant was then subjected to silica gel column $(\phi 3 \times \mathrm{L} 30 \mathrm{~cm})$ and eluted with petroleum ether/acetone to yield compound $\mathbf{2}(9 \mathrm{mg})$. Compound $\mathbf{3}(31 \mathrm{mg})$ was obtained by crystallization of fraction $\mathrm{B}$ from petroleum ether/ethyl acetate $(3: 1)$. Compound 4 $(5 \mathrm{mg})$ was obtained by HPLC (C-18 column, $\left.\mathrm{CH}_{3} \mathrm{CN}: \mathrm{H}_{2} \mathrm{O}, 65: 35\right)$ from fraction $\mathrm{C}$. The fraction $\mathrm{D}$ was subjected to silica gel column chromatography $(\phi 3 \times \mathrm{L} 30 \mathrm{~cm})$ and eluted with petroleum ether/acetone $(2: 1$ to $1: 1)$ to give fractions D1, D2. Compound $\mathbf{5}(20 \mathrm{mg})$ was obtained by crystallization of fraction D1 from petroleum ether/acetone, and compound $\mathbf{6}(15 \mathrm{mg})$ was obtained by crystallization of fraction $\mathrm{D} 2$ from petroleum ether/acetone.

Herpetolide A (1): White amorphous powder. mp $95-96.5^{\circ} \mathrm{C} .{ }^{1} \mathrm{H}-$ and ${ }^{13} \mathrm{C}$-NMR data see Table 1 . IR (KBr) $\mathrm{cm}^{-1}: 3384,1688,1612,1522,1453$, 1308, 1155. UV $\lambda_{\max }\left(\mathrm{CH}_{3} \mathrm{OH}\right) \mathrm{nm}(\log \varepsilon): 260$ (3.64), 303 (3.18), 335 (2.88). HR-ESI-MS $m / z: 325.0682$ (Calcd for $\mathrm{C}_{16} \mathrm{H}_{14} \mathrm{O}_{6} \mathrm{Na}:[\mathrm{M}+\mathrm{Na}]^{+}$, 325.0683). MS $m / z: 302\left(\mathrm{M}^{+}\right), 285,84$.

Herpetolide B (2): White amorphous powder. mp $105-107^{\circ} \mathrm{C} .{ }^{1} \mathrm{H}-$ and ${ }^{13} \mathrm{C}$-NMR data see Table 1 . IR ( $\left.\mathrm{KBr}\right) \mathrm{cm}^{-1}: 3356,1725,1674,1622,1523$, 1455, 1315,1159. UV $\lambda_{\text {max }}\left(\mathrm{CH}_{3} \mathrm{OH}\right) \mathrm{nm}(\log \varepsilon): 247$ (3.84), 304 (3.30), 346 (3.22). HR-ESI-MS $m / z$ : 323.0523 (Calcd for $\mathrm{C}_{16} \mathrm{H}_{12} \mathrm{O}_{6} \mathrm{Na}:[\mathrm{M}+\mathrm{Na}]^{+}$, 323.0527). MS $m / z: 300\left(\mathrm{M}^{+}\right), 272,257,113$.

Protective Effects of Herpetone on Primary Cultured Rat Hepatocytes Treated with $\mathbf{C C l}_{4}$ Hepatocytes were obtained from rat liver by means of collagenase perfusion method. ${ }^{9}$ Cell suspensions were seeded into 96-well-plates $\left(\geq 4 \times 10^{4}\right.$ cells/well $)$ and incubated at $37^{\circ} \mathrm{C}$ in a humidified atmosphere of $5 \% \mathrm{CO}_{2}$ for $48 \mathrm{~h}$. $\mathrm{CCl}_{4}$ was then added to the culture medium at a final concentration of $8 \mathrm{mmol} / 1$ to induce hepatocyte injury. After $24 \mathrm{~h}$, herpetone of various concentrations were added to the culture medium and the cells were further cultured for $48 \mathrm{~h}$ followed by the addition of $50 \mu \mathrm{l}$ of 3-(4,5-dimethylthiazol-2-yl)-2,5-diphenyltetrazolium bromide (MTT) solution $(5 \mathrm{mg} / \mathrm{ml})$ into each well. The cells were incubated under the same conditions for additional $4 \mathrm{~h}$. Then, the culture medium was removed. After the addition of $150 \mu 1$ of DMSO, the optical densities at $570 \mathrm{~nm}$ were measured and the survival rates of hepatocytes were calculated [survival rate $=\mathrm{OD}$ (sample group)/OD (medium group) $\times 100 \%]$.

Acknowledgements This work was financially supported by Sichuan Provincial Education Department. The authors are grateful to Chengdu Institute of Biology of the Chinese Academy of Sciences for the determination of HR-ESI-MS and NMR spectra.

\section{References}

1) "The Drug Standard of Ministry of Health of P. R. China (Tibetan Medicines)," Vol. 9, ed. by State Pharmacopoeia Committee of P. R. China, 1995, p. 641.

2) Zhang M., "Ph. D. Dissertation of Chengdu University of Traditional Chinese Medicine," Chengdu University of Traditional Chinese Medicine, Chengdu, 2003, pp. 46-51.

3) Zhang M., Dong X. P., Deng Y., Wang H., Li X. N., Song Q., Acta Pharm. Sinica, 41, 659-661 (2006).

4) Salama O., Chaudhuri P. K., Sticher O., Phytochemistry, 20, 26032604 (1981).

5) Ellis P. D., Dunlap R. B., Pollard A. L., Seidman K., Cardin A. D., J. Am. Chem. Soc., 95, 4398- 4403 (1973).

6) Zhang X. Q., Qi J., Ye W. C., Zhao S. X., J. Chin. Pharm. Univ., 35, 404-405 (2004).

7) Tanahashi T., Kuroishi M., Kuwahara A., Nagakura N., Hamada N., Chem. Pharm. Bull., 45, 1183-1185 (1997).

8) Yuan H. L., Liu Y., Zhao Y. L., Xiao X. H., J. Chin. Pharm. Sci., 14, 140-143 (2005)

9) Tan H. L., Yang M. H., Wang Y. G., Ma Z. H., Gao Y., Chin. J. Appl. Physiol., 22, 509-512 (2006). 